\title{
CELLULAR IMPACT OF METAL TRACE ELEMENTS ON THE LICHEN LOBARIA PULMONARIA (L.) HOFFM. (1796), A BIO INDICATOR OF ATMOSPHERIC POLLUTION AND IDENTIFICATION OF ITS ANTIOXIDANT RESPONSE
}

\author{
Kouadria, N. ${ }^{*}$ - Alioua BerrebBah, A. - Belhoucine, F. - Bouredja, N. - AitKaCi, M. \\ Laboratoire de Toxicologie Environnement et Santé (LATES), Faculté des sciences de la nature \\ et de la vie, Université des Sciences et de la Technologie d'Oran Mohamed Boudiaf USTO-MB, \\ BP 1505, el M'naouer, 31000 Oran, Algérie \\ (phone: +213-699-135-342) \\ *Corresponding author \\ e-mail: Nawel.kouadria@univ-usto.dz \\ (Received $5^{\text {th }}$ Aug 2021; accepted $1^{\text {st }}$ Oct 2021)
}

\begin{abstract}
We used the bioindicator Lobaria pulmonaria (L.) Hoffm. to assess air pollution, particularly induced by heavy metals, in urban and peri urban regions in the city of Oran (N-W of Algeria) and evaluated their environmental impact. For this purpose, we adopted the active biomonitoring technique to monitor lead $(\mathrm{Pb})$, Cadmium $(\mathrm{Cd})$ and Chromium $(\mathrm{Cr})$ bioaccumulation in transplanted Lobaria pulmonaria thalli and assessed the detoxification enzyme's activity: Catalase (CAT), Ascorbate peroxidase (APX), and Guaiacol peroxidase (GPX) to examine the antioxidant system's response to heavy metal-induced stress. This study, revealed significant bioaccumulation of $\mathrm{Pb}, \mathrm{Cd}$ and $\mathrm{Cr}$ in the following order $\mathrm{Pb}>\mathrm{Cr}>\mathrm{Cd}$, increasing significantly in time reaching $301.83 \mathrm{mg} / \mathrm{kg}$ with the highest concentrations recorded in the urban regions indicating high metallic pollution levels. Additionally, heavy metal concentrations were proven to be significantly correlated with the over expression of detoxification enzymes. The response of Lobaria pulmonaria to air quality, along with its bio-accumulative capacity, confirmed that it is indeed a good bio-indicator of atmospheric pollution, especially that induced by heavy metals.
\end{abstract}

Keywords: ecotoxicology, bio monitoring, xenobiotic, bioaccumulation, bioindication, air pollution

\section{Introduction}

Air pollution is a significant ecological issue worldwide, which, as per the World Health Organization, influences the majority of the world's population (WHO, 2018). Some activities generating progress and modernity in the urban communities, notably economic activities, industrialization and expansions in street traffic, in addition to the population growth, have caused a significant increase in air pollution levels, affecting humans and the ecosystem (Bouteraa, 2014; Rahal et al., 2018; Jiang et al., 2018). Indeed, previous studied found that pollutants of road emission origin are the most ubiquitous group of pollutants detected in plants tissues (Akomolafe et al., 2019).

Air pollution incorporates a range of pollutants emitted frequently into the air, among which heavy metals (HMs), essentially resulting from road traffic, represent an important group (Belhadj, 2015). The danger of these non-biodegradable hazardous materials results from the fact that once in the atmosphere, they can travel several kilometers away from emission sources upon wind direction (Shahid et al., 2017), and are capable to remain in nature through biomagnification, affecting thus human and environment even in areas far from contamination sources (Mahapatra et al., 2019). 
The deterioration of air quality has severe consequences on human health. According to Çomaklı and Bingöl (2021), the exposure of humans to important heavy metals contents often causes serious health problems. Moreover, a lot of papers have also highlighted air pollution's impact on the environment including lichens, and proved that heavy metal are responsible for altering physiological and morphological characteristics of these plants since lichens are sensitive to atmospheric changes and micro-climatic conditions (Akomolafe et al., 2019; Ilondu, 2019). Indeed, the impact of these hazardous depends on their concentration, their chemical properties, and on the resistance or the sensibility of the contaminated species (Kaur et al., 2021). However, even if heavy metal combinations are common in nature, their combined effects have not been extensively studied (Tkalec et al., 2014).

As in many countries in the world, Algerian urban population continues to rise. In the western region, the city of Oran in particular, the regional metropolis and the country's second-largest city, has known over the last decade a strong urbanization, reflected in a vast urban territory and numerous extensions, which has led to more and longer trips, mostly made by individual motorized transport. This, in addition to its industrial infrastructure, has led to an increase in atmospheric emissions (Kadri and Madani, 2015; Rahal et al., 2018) In addition, some topographical, geographical and climatic characteristics like humidity and dominant wind speed lead to a considerable increase in pollution levels in the various ecosystems, and more particularly in air (Stankevich et al., 2015).

Due to a lack of appropriate instrumentation for monitoring air quality in Oran region, it became necessary to develop a bio monitoring system based on an alternative method of air quality assessment, involving bio-indicators. This use is based on their integrative nature regarding environmental factors. Indeed, "living beings are a reflection of the environment in which they evolve and their observations at the various levels of biological organization can provide indications of the quality of this environment" (Guelorget et al., 1986). Biomonitoring includes the use of different matrices among which lichens are the most used over the last years, because of their morphological properties since they get their nutriment directly from ambient air due to the absence of root and cuticle layer. In addition, lichens are very sensitive to environmental conditions which allows them reacting to ecological changes reflecting thus the environmental conditions, and also have an important bioaccumulation capabilities allowing them indicating the concentrations of atmospheric bio accumulated pollutants, as well as their spatial distribution (Deruelle, 1978, 1983; Tyler, 1989; Alioua, 1995; Alioua, 2001; Alioua et al., 2008; Garrec and Van Haluwyn, 2002; Yemets et al., 2014; Kłos et al., 2018; Jiang et al., 2018; Ramade, 2007; Rola, 2020).

In Algeria, bio-monitoring studies using lichens were conducted largely in the central and eastern regions (Rahali, 2002; Semadi and Deruelle, 1993; Alioua, 2001; Alioua et al., 2008; Belhadj, 2015). However, according to the Oran's Directorate of Environment, no atmospheric biomonitoring study has ever been conducted in this region (DOE, 2018).

The aim of this work is to investigate atmospheric heavy metal contents using the bio indicator Lobaria pulmonaria (L.) Hoffm. in the region of Oran, as an alternative approach in air quality assessment, and to assess the impact of these heavy metals on the studied species through examining the response of the plant's antioxidant system to these stressors. 


$$
-4723 \text { - }
$$

\section{Materials and methods}

\section{Study area}

The study region is located in the southwest of the Mediterranean (north-west of Algeria $35^{\circ} 42 \mathrm{~N}$ and $00^{\circ} 36 \mathrm{~W}$ ). This region belongs to the semi-arid Mediterranean bio climatic zone with a six-month dry season (April to October with rare rainfall exceeding barely $30 \mathrm{~mm}$ ) and abundant rainfall in winter. In addition, winds blow mainly from the north $(19 \%)$ at $12 \mathrm{~m} / \mathrm{s}$ and from the west $(18 \%)$ at more than $17 \mathrm{~m} / \mathrm{s}$, with three other directions: southwest (14\%), northeast $(10 \%)$ and east $(7 \%)$ reaching a maximum speed of $8 \mathrm{~m} / \mathrm{s} .30 \%$ of the time, the wind is calm $(<1 \mathrm{~m} / \mathrm{s})$. (Bendaikha and Hadjadj-Aoul, 2016). Moreover, the region of Oran is characterized by an important car fleet estimated at 357,988 in 2017, mainly in the Oran agglomeration, where the majority were vehicles in use for more than 20 years (OTD, 2018).

This study has been conducted in twelve different sites in Oran covering both urban and peri urban region (Fig. 1; Table 1).

\section{Transplantation and sampling}

In this study we adopted the transplantation technique developed by (Brodo, 1961), which consists in introducing bio-indicators taken from a control site into the study sites (Fig. 2). We chose a foliaceous species, Lobaria pulmonaria (L.) Hoffm. an epiphytic lichen resulting from the symbiosis of a green algae and a cyanobacterium, while the fungus (Ascomycetes) provides protection against dehydration, the green algae (Dictyochloropsis reticulata) produces the carbohydrates necessary for the organism, and the cyanobacterium (Nostoc) allows the capture of atmospheric nitrogen necessary for growth (Carlsson and Nilsson, 2009).

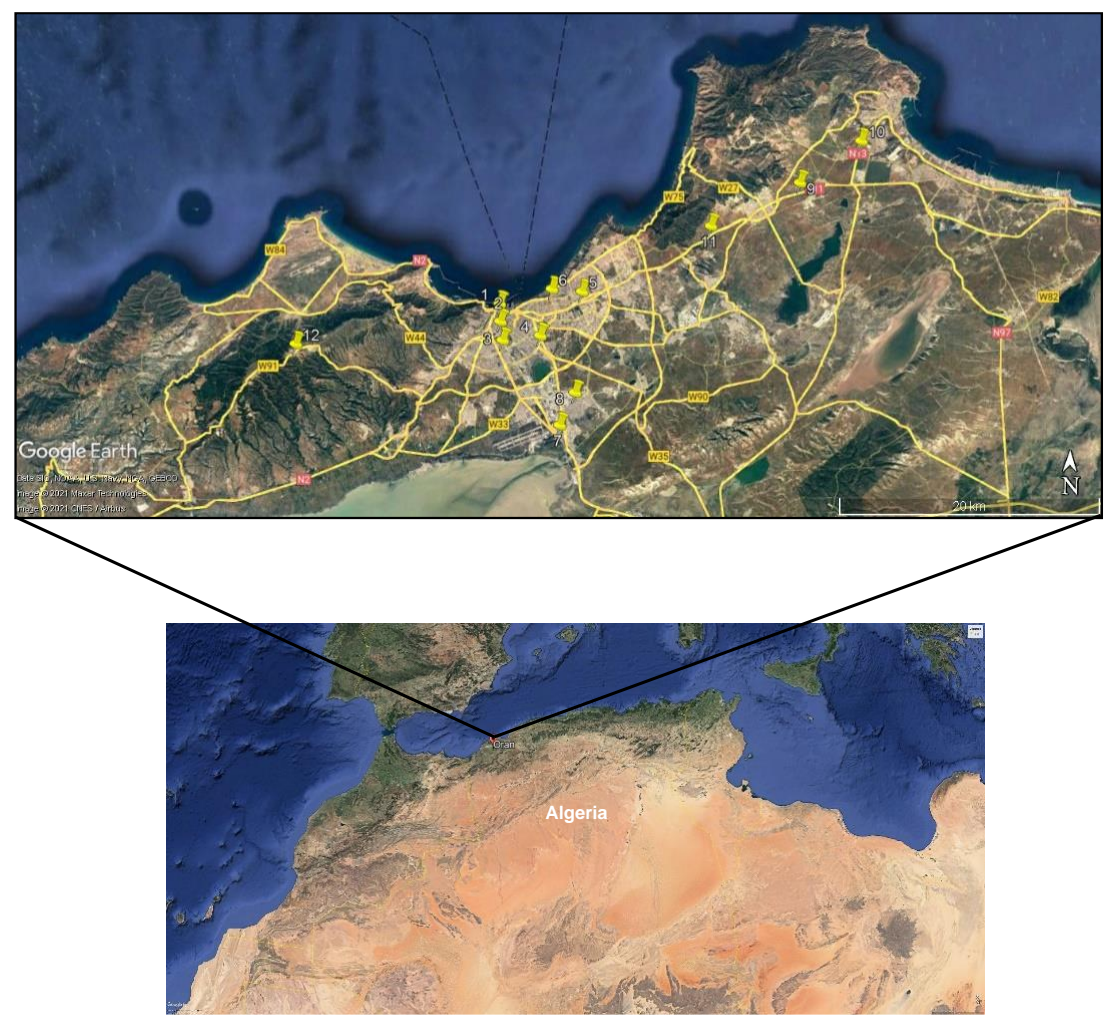

Figure 1. Geographical location of the study sites 


$$
\text { - } 4724 \text { - }
$$

Table 1. Description and geographical location of the study sites

\begin{tabular}{|c|c|c|c|c|}
\hline $\begin{array}{l}\text { Site } \\
\text { No. }\end{array}$ & Site description & Longitude/E & Latitude/N & Altitude (m) \\
\hline 1 & \begin{tabular}{|} 
An urban site located in the center of Oran next to the \\
Pasteur high school, $20 \mathrm{~m}$ from the ALN boulevard on the \\
seafront overlooking the port of Oran, and $20 \mathrm{~m}$ from a bus \\
stop, this site is exposed to heavy road traffic and \\
pedestrian traffic
\end{tabular} & $0 \circ 38$ '44.62” & $35^{\circ} 42^{\prime} 18.64^{\prime \prime}$ & 60 \\
\hline 2 & $\begin{array}{c}\text { An urban site located in the center of Oran, next to the } \\
\text { largest popular market in the city with a high pedestrian } \\
\text { traffic during the day. This site is located } 39.78 \mathrm{~m} \text { from the } \\
1 \text { st November } 1950 \text { roundabout with a huge road traffic as } \\
\text { it leads to one of the biggest hospitals in Oran }\end{array}$ & $0^{\circ} 38^{\prime} 41.47^{\prime \prime}$ & $35^{\circ} 41^{\prime} 34.52^{\prime \prime}$ & 110 \\
\hline 3 & $\begin{array}{c}\text { An urban site characterized by a high density as it is located } \\
\text { next to a middle school, and intense road traffic since it is } \\
\text { situated at } 72 \mathrm{~m} \text { from the second peripheral highway and at } \\
155.35 \mathrm{~m} \text { from the ANP roundabout }\end{array}$ & $0^{\circ} 38^{\prime} 32.93 ”$ & $35^{\circ} 40^{\prime} 48.35^{\prime \prime}$ & 102 \\
\hline 4 & $\begin{array}{c}\text { An urban site located in the center of the city at } 20.30 \mathrm{~m} \\
\text { from one of the largest roundabouts characterized by heavy } \\
\text { road traffic, especially since it provides transportation to } \\
\text { and from the main bus station which is } 480.59 \mathrm{~m} \text { away } \\
\text { this site located near two service stations (at } 383 \mathrm{~m} \text { and } \\
329 \mathrm{~m} \text { ) }\end{array}$ & 0³6’39.30" & $35^{\circ} 41^{\prime} 2.23^{\prime \prime}$ & 90 \\
\hline 5 & $\begin{array}{c}\text { an urban site located } 10 \mathrm{~m} \text { from a big roundabout, } \\
\text { characterized by heavy traffic due to the presence of a bus } \\
\text { station that considerably disturbs the traffic }\end{array}$ & $0^{\circ} 34^{\prime} 35.89^{\prime \prime}$ & $35^{\circ} 42^{\prime} 53.12^{\prime \prime}$ & 147 \\
\hline 6 & $\begin{array}{l}\text { An urban site located } 21 \mathrm{~m} \text { from a large roundabout, it is } \\
\text { located in the middle of a built-up area near several } \\
\text { intersections. This site has physical and aesthetic } \\
\text { characteristics suitable for high traffic and high density }\end{array}$ & $0^{\circ} 36^{\prime} 7.39^{\prime \prime}$ & $35^{\circ} 42^{\prime} 57.59^{\prime \prime}$ & 161 \\
\hline 7 & $\begin{array}{c}\text { A peri-urban site located in the middle of a roundabout. } \\
\text { This site is near to Oran's airport and is located at } 692.46 \mathrm{~m} \\
\text { from the national road N4, and } 2.95 \mathrm{~km} \text { from the Es Senia } \\
\text { industrial zone }\end{array}$ & $0^{\circ} 35^{\prime} 33.13^{\prime \prime}$ & $35^{\circ} 37^{\prime} 23.42^{\prime \prime}$ & 89 \\
\hline 8 & $\begin{array}{c}\text { A peri-urban site located in the center of the industrial zone } \\
\text { of Es Senia, and at } 886.04 \mathrm{~m} \text { from the national road N4 }\end{array}$ & $0^{\circ} 34^{\prime} 49.07^{\prime \prime}$ & $35^{\circ} 38^{\prime} 44.55^{\prime \prime}$ & 90 \\
\hline 9 & $\begin{array}{c}\text { A peri-urban site located in the east of the Oran on the edge } \\
\text { of the national road N11 linking the industrial zone of } \\
\text { Arzew to the town of Oran, which is characterized by } \\
\text { heavy traffic, especially during rush hours. This site is } \\
\text { located } 1.6 \mathrm{~km} \text { from a gas station and } 5.7 \mathrm{~km} \text { from the } \\
\text { industrial zone of ARZEW }\end{array}$ & $0{ }^{\circ} 23$ '41.52” & $35^{\circ} 47^{\prime} 34.31^{\prime \prime}$ & 152 \\
\hline 10 & $\begin{array}{c}\text { A peri-urban site located in the east of Oran on the edge of } \\
\text { the national road N13 at } 69.69 \mathrm{~m} \text { from the industrial pole of } \\
\text { Arzew. } \\
\text { The site is located } 1.85 \mathrm{~km} \text { from the Arzew refinery, } \\
2.18 \mathrm{~km} \text { from the power station and } 1.41 \mathrm{~km} \text { from the } \\
\text { Sorfert company known for its toxic emissions }\end{array}$ & $0^{\circ} 20^{\prime} 37.72 ”$ & 3549'20.91" & 82 \\
\hline 11 & $\begin{array}{c}\text { A peri-urban site located in the east of Oran on the edge of } \\
\text { the national highway N11 and at } 13.42 \mathrm{~km} \text { from the } \\
\text { industrial zone of Arzew }\end{array}$ & $0^{\circ} 28^{\prime} 9.19^{\prime \prime}$ & $35^{\circ} 45^{\prime} 42.36^{\prime \prime}$ & 124 \\
\hline 12 & $\begin{array}{l}\text { A peri-urban site located in the middle of the forest of } \\
\text { Msila in the West of Oran, however this region is the } \\
\text { favorite destination of Oranese to make outings, camping } \\
\text { and picnik during which they opt for the combustion to } \\
\text { prepare their meals }\end{array}$ & $0^{\circ} 49^{\prime} 1.09^{\prime \prime}$ & $35^{\circ} 40^{\prime} 25.06^{\prime \prime}$ & 507 \\
\hline
\end{tabular}



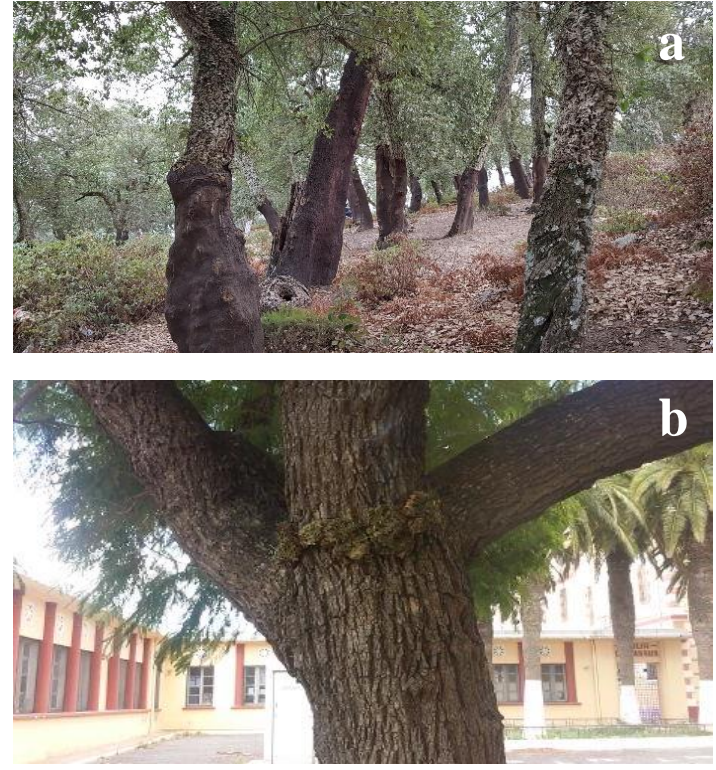

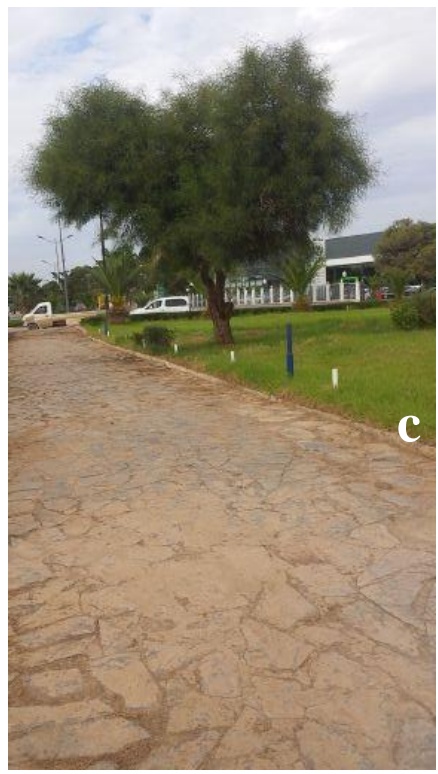

Figure 2. Habitat of the lichen Lobaria pulmonaria and the followed transplantation technique. (a) habitat, (b) lichenic thalli transplnated in the urban site (1), (c) the peri-urban site (7)

The thallus of Lobaria pulmonaria were collected with their phorophytes from a control site, located in the Seraidi forest $36^{\circ} 55 \mathrm{~N}$ and $7^{\circ} 40 \mathrm{E}$ in northeastern Algeria, located far from major sources of pollution, and then transplanted to the study sites (Fig. 1), at a height varying from $1.5 \mathrm{~m}$ to $2 \mathrm{~m}$ (Fig. 2b). We carried monthly sampling during seven months from December 2018 to June 2019 in order to perform the various measurements.

\section{Analysis and measurement}

\section{Heavy metal analysis}

We followed Deruelle (1978) technique for samples digestion. After drying samples for $72 \mathrm{~h}$ at $105^{\circ} \mathrm{C}$, they were crushed, placed in pill boxes and treated with $30 \%$ pure RP Norma hydrogen peroxide $\mathrm{H}_{2} \mathrm{O}_{2}$ until complete digestion. The digestion took place in an oven set at $90{ }^{\circ} \mathrm{C}$ for $72 \mathrm{~h}$. Lead $(\mathrm{Pb})$, chromium $(\mathrm{Cr})$ and cadmium $(\mathrm{Cd})$ analysis were performed using the ICP-OES Thermo Scientific iCAP 7000 (France). HM analysis include the HM particles deposited on lichen surface. For each heavy metal and for each site three replicates were carried out.

\section{Enzyme assays}

The investigation of enzymatic activity was proceeded in two stages. First, we prepared the enzyme extract from collected transplants and from the control site following the protocol of Loggini et al. (1999). The enzyme extract is used to prepare the reaction mixture respective for each enzyme CAT, APX and GPX.

The catalase optical density is obtained at $240 \mathrm{~nm}$ following (Cakmaki, 1991) technique, the Ascorbate-peroxidase's optical density is obtained at $290 \mathrm{~nm}$ following (Nakano and Asada, 1987) technique and the Guaiacol peroxidase's optical density is obtained at $470 \mathrm{~nm}$ following (Fielding and Hall, 1978) technique. The 
spectrophotometer used is a UV-VIS spectrophotometer (190-1000 nm) - JENWAY (France). For each enzyme and for each site three replicates were carried out (Fig. 3).
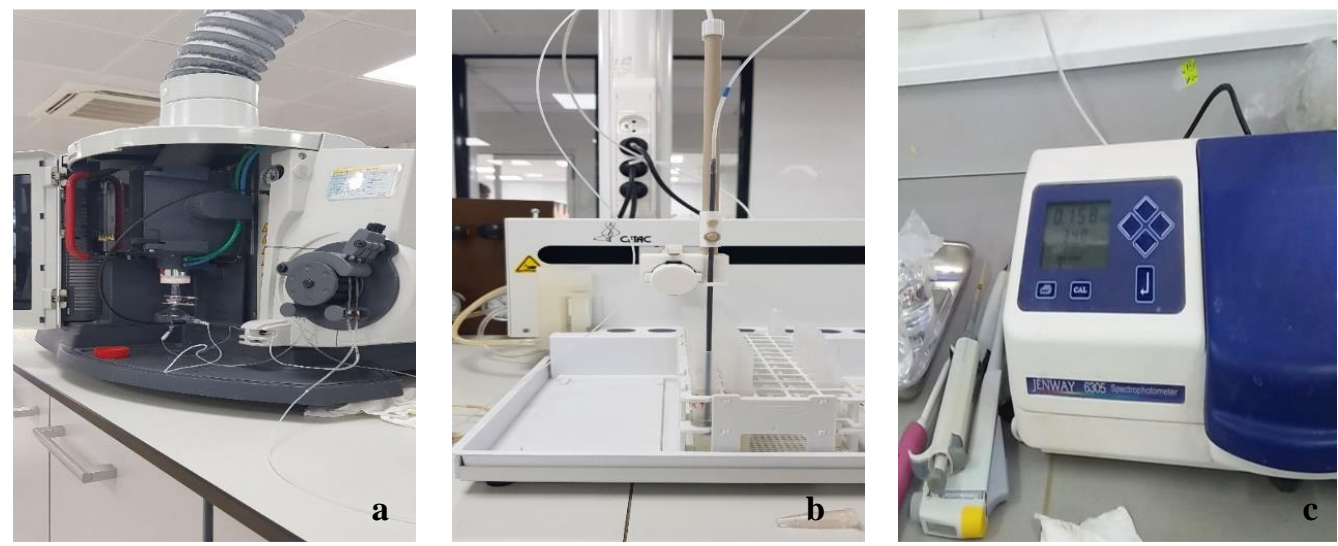

Figure 1. Analysis and dosages in laboratory ( $a$ and $b$ ) HMs analysis by ICP-OES, (c) enzymatic activity analysis by UV-VIS spectrophotometer

\section{Statistical analysis}

The obtained data were subjected to a statistical analysis:

- The two ways ANOVA is conducted for $\mathrm{Pb}, \mathrm{Cd}, \mathrm{Cr}, \mathrm{APX}, \mathrm{GPX}$ and CAT in order to study the significance of the spatio-temporal variation of each parameter.

- We carried out a two-way ANOVA with co-variates for the three enzymes in order to investigate the influence of heavy metal accumulation on the spatiotemporal variation of the enzymatic activity.

- Post Hoc tests were carried out, notably the Tukey test to determine the significance between homogeneous group means and the Dunnett test to determine the significance between homogeneous group means and the control mean.

- The correlation analyses between $\mathrm{Pb}, \mathrm{Cd}, \mathrm{Cr}$ concentrations and APX, CAT, GPX activities were conducted using a bivariate correlation test with Pearson's correlation coefficient.

XLstat and Minitab software packages were used to conduct the statistical analysis.

\section{Results and discussion}

\section{Heavy metals results}

In general, the spatio-temporal variations in HM concentrations show that for the three metals $\mathrm{Pb}, \mathrm{Cd}$ and $\mathrm{Cr}$, the concentrations tend to increase from the first sampling comparing to control, regardless of the site in the following order $\mathrm{Pb}>\mathrm{Cr}>\mathrm{Cd}$ (Fig. 4). These concentrations varies depending on the study sites and continue to increase significantly $(\mathrm{p}=0.000 * * *)$ to reach a maximum of $301.83 \mathrm{mg} / \mathrm{kg}$ of $\mathrm{Pb}$ at site 5 during the last sampling of June. Moreover, results show a significant increase in Cd concentrations $\left(\mathrm{p}=0.000^{* * *}\right)$ with a predominance in sites $1,4,6$ and 10 where we record close highest concentrations during the month of June. 


$$
-4727-
$$
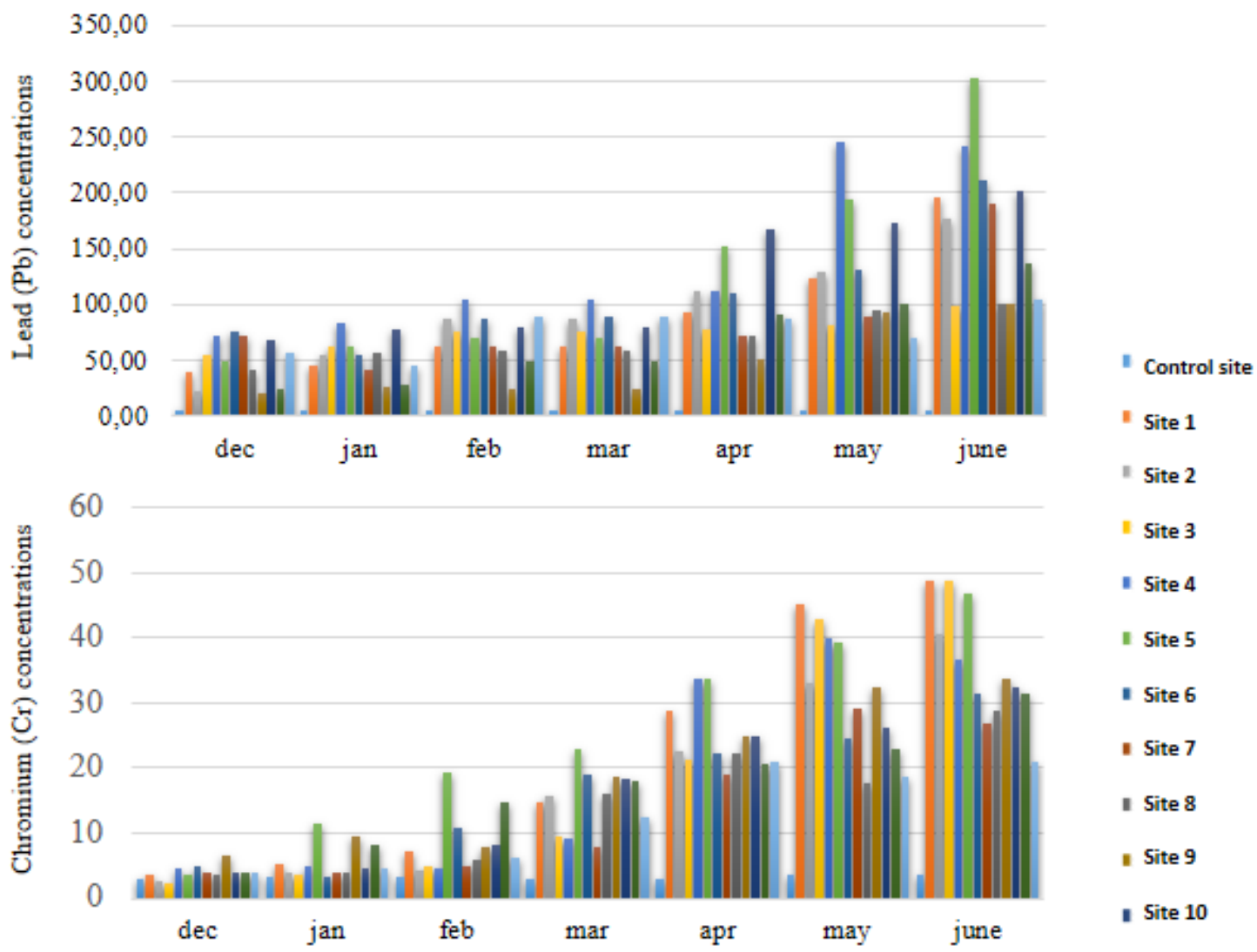

" Site 1

"Site 2

"Site 3

- Site 4

1) Site 5

- Site 6

1 Site 7

1. Site 8

I Site 9

1. Site 10

I. Site 11

- Site 12

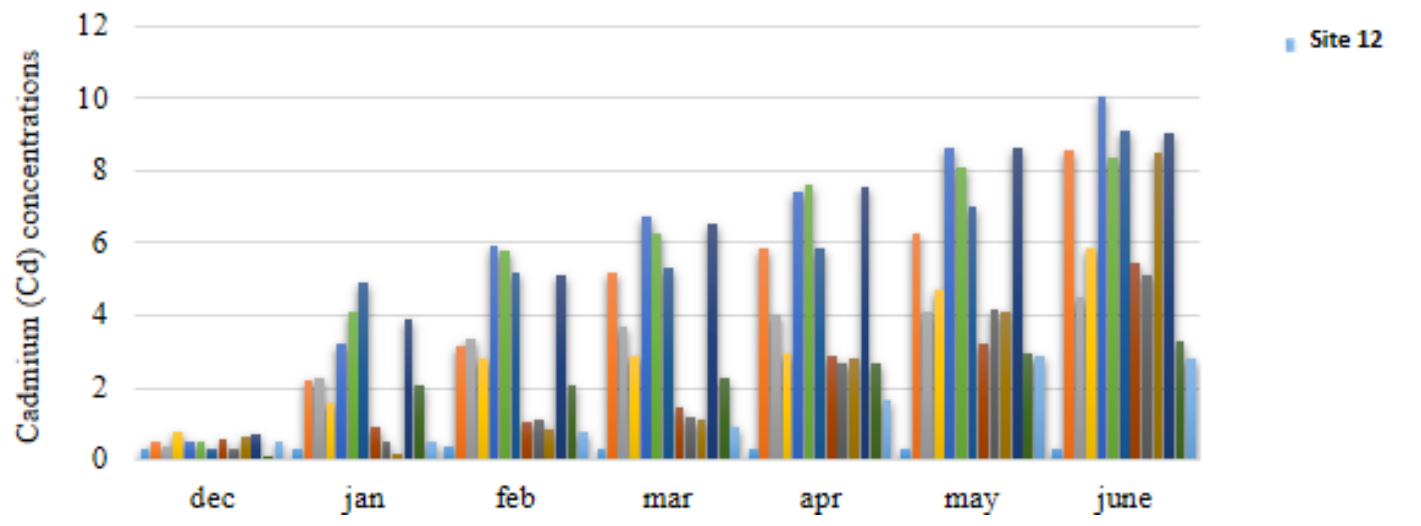

Figure 4. Spatio-temporal heavy metal (lead (Pb), Cadmium (Cd), Chromium $(\mathrm{Cr})$ ) concentrations $(\mathrm{mg} / \mathrm{kg} \mathrm{DW})$ bioaccumulated in thallus of Lobaria pulmonaria

The results of post hoc tests for spatio-temporal heavy metal concentrations are shown in (Fig. 5). These results allow identifying site-specific and month-specific fluctuations in bioaccumulated heavy metal concentrations. In space, according to Tukey test the highest averages of $\mathrm{Pb}, \mathrm{Cd}$ and $\mathrm{Cr}$ are recorded in site four. Averages of site four are significantly different from the control according to Dunnet test. However, in time, according to Tukey test, averages of $\mathrm{Pb}, \mathrm{Cd}$ and $\mathrm{Cr}$ increase to reach maximum averages in the last month, these averages are significantly different from the control according to Dunnet test. The spatial variation of obtained HM concentrations made it possible to locate the most contaminated sites, since the bioavailability of these elements allows their bioaccumulation (Rola, 2020). 

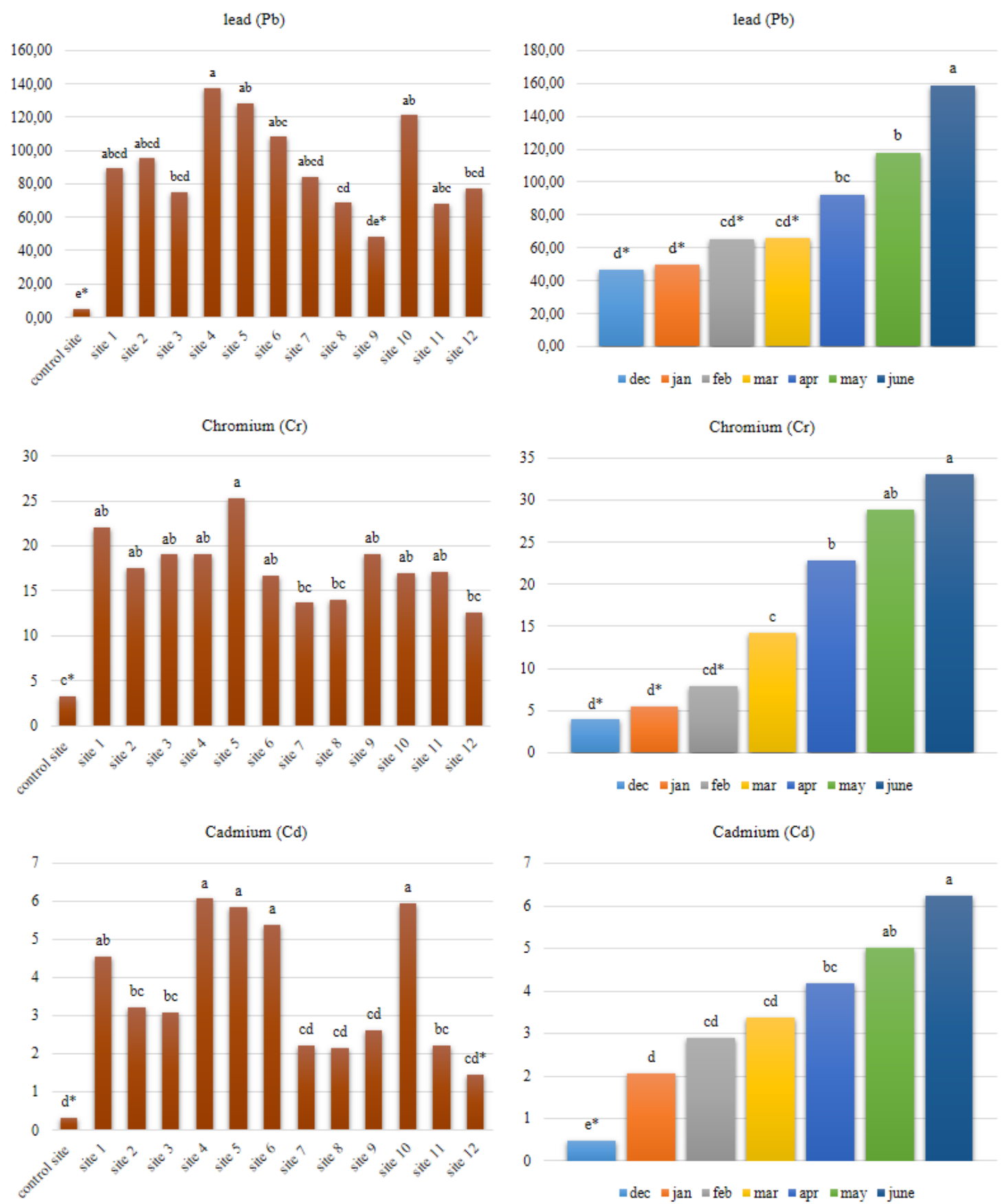

Figure 5. Heavy metal means recorded in space and in time in Lobaria pulmonaria thallus. The different letters show significant differences according to Tukey's HSD $(p<0.05)$. Means not marked with $a(*)$ are significantly different from the control site's mean according to Dunnet $(p<0.05)$

Indeed, the concentrations of $\mathrm{Pb}, \mathrm{Cd}$ and $\mathrm{Cr}$ bio-accumulated by transplants increase the closer they get to urban sites, in particular sites 1, 2, 4, 5 and 6, since urban sites are characterized by dense automobile traffic and high population concentration (Hamutoğlu et al., 2017; Kaur et al., 2021; Çomaklı and Bingöl, 2021). In fact, many studies reported a significant correlation between road traffic and the accumulation of HMs like, Pb, such as Belhadj (2015), Maizi and Alioua (2015), Rahali (2002) and 
Semadi and Deruelle (1993) in Algeria, Tkalec et al. (2014) in Finland, and Abas et al. (2019) in Malaysia. Other factors, such as topographic variations, may also have an impact on HMs rated in the environment, especially in lichens. According to the work of Belhadj (2015), atmospheric particle concentrations are higher in low altitude areas than on slopes and mountains; this topographic factor explains the relatively low concentrations of HMs recorded in site 12 which is located in a mountainous region. These factors are in addition to lichens complex accumulation mechanisms, which are influenced by a variety of factors such as age, thallus size, and species-specific characteristics (Alami et al., 2014). According to Rahma et al. (2014), HM presence in the thallus of transplants is essentially associated with the lichen's accumulative potential, which is attributable to the physiological properties of lichens allowing them to maintain pollutants in their tissues. Moreover, due to the lack of surface protective barriers, the thallus of lichens are highly permeable to airborne pollutants, especially heavy metals, considered as a major component of air pollution (Álvarez et al., 2015; Hamutoğlu et al., 2017). According to Garty et al. (1998) and Belhadj (2015), the capacity of lichens to absorb metals is directly related to their morphological and anatomical structures since lichens accumulate more HMs as their surface area increases.

In addition, Angold (1997) reported that atmospheric pollutants from traffic origin are likely to contaminate natural vegetation located $80 \mathrm{~m}$ to $200 \mathrm{~m}$ from the road, while Viskari and Kärenlampi (2000) reported in a study conducted on snow samples and moss bags, collected 30 to $60 \mathrm{~m}$ from the road, a distance-dependent decrease in the deposition of inorganic air pollutants (Yemets et al., 2014), which explains the results we recorded in site 10 of our study, which recorded significant concentrations of $\mathrm{Pb}, \mathrm{Cd}$ and $\mathrm{Cr}$, although it is located far from the agglomeration. Indeed, this site is located on the side of the street that connects the agglomeration of Oran to the largest industrial zone of the country "Arzew", which has an important road traffic, especially at peak hours, in addition to industrial discharges, considered as an important emissions source of HMs (Yemets et al., 2014). Furthermore, according to the obtained results, in the peri-urban sites located far from the city, notably sites 3, 7, 8 and 9, recorded HM concentrations are relatively low compared to the urban sites. These results are consistent with those of many authors who have studied the deposition of road pollutants according to distance from the road (Agnan et al., 2017; Kłos et al., 2018; McAdam et al., 2011; Pagotto et al., 2001; Škrbić et al., 2012). In particular, Yemets et al. (2014) found that the accumulation of $\mathrm{Cr}, \mathrm{Pb}$ and $\mathrm{Cd}$ decreases with increasing distance from the source of pollution.

Furthermore, the temporal variation of concentrations bioaccumulated by transplants over time shows the increasing of the levels of $\mathrm{Pb}, \mathrm{Cd}$ and $\mathrm{Cr}$, indeed, the literature usually reports on the temporal rises and decreases of the HMs accumulated by lichens. In fact, our experiment was conducted over two seasons, a winter season including the first three months, for which statistical analysis recorded the lowest concentrations of $\mathrm{HMs}$, and a spring-summer season with higher concentrations of HMs, which is consistent with the results of Belhadj (2015), Maizi and Alioua (2015) and Abas et al. (2019). This temporal variation can be correlated with the environmental conditions that may influence the bioaccumulation of HMs (Agnan et al., 2017). In general, the wet season is marked by an important rainfall and a relatively high frequency of winds, as in the case of Oran, with rainfall up to $513 \mathrm{~mm}$, and a dominant wind direction from North to West (18\%) at $12 \mathrm{~m} / \mathrm{s}$ and from South-East to East at a speed of $17 \mathrm{~m} / \mathrm{s}$ (Bendaikha 
and Hadjadj-Aoul, 2016). According to Alami et al. (2014) rainfall causes atmospheric purification and contributes to the leaching of pollutants from lichen thallus. Moreover, the impact of winds on atmospheric pollutant's travelling seems to have a great influence on the accumulation of the pollutant (Semadi and Deruelle, 1993; Belhadj, 2015).

In addition, high concentrations of HMs during the summer period may also be correlated with the increase in pollution rates, due to the increase in road traffic intensity, and also to other factors such as: the effect of slope, long periods of drought, and the unequal distribution of road traffic which is reflected in the high concentrations of pollutants that remain in the atmosphere for a relatively long period (Belhadj, 2015). In addition, many papers reported that the concentrations of HMs absorbed in lichen samples are also influenced by exposure time (Garty et al., 1998; Yemets et al., 2014; Nimis et al., 2002). Hamutoğlu et al. (2017) also found significant accumulation of HMs after 6 months of transplantation along a highway, while Agnan et al. (2017) found that bioaccumulated amounts of HMs reached $964 \mathrm{mg} / \mathrm{kg}$ after 3 years of exposure.

\section{Enzyme assay results}

The spatio-temporal variation of the three enzymes CAT, APX and GPX shown in (Fig. 6) follows the same tendency as HMs. CAT variation is very highly important in space, according to the two-way ANOVA $\left(\mathrm{p}=0.000^{* * *}\right)$ and highly significant in time $\left(\mathrm{p}=0.003^{* *}\right)$. CAT levels tend to increase to reach a maximum of $3.93 .10^{8}$ $\mathrm{nmol} / \mathrm{min} / \mathrm{mg}$ recorded in site 2 during the sampling of June. In addition, APX rates increase gradually to reach a maximum value of $901.67 .10^{8} \mathrm{nmol} / \mathrm{min} / \mathrm{mg}$ in site 2 during the sampling of June. Based on the two ways ANOVA, variation in APX is not significant in space $(p=0.432)$ and very highly significant in time $(p=0.000 * * *)$. Moreover, maximum GPX activity reaches $23.47 .10^{-8} \mathrm{nmol} / \mathrm{min} / \mathrm{mg}$ at site 4 in June. Variation in GPX activity is very highly significant in space and time ( $\left.\mathrm{p}=0.000^{* * *}\right)$. The results of post hoc tests for spatio- temporal enzymatic activity (Fig. 7) allows identifying site-specific and month-specific fluctuations in enzymatic response. According to Tukey's test, the monthly averages of the APX increase significantly from the sixth month. While monthly averages of CAT increase significantly from the $5^{\text {th }}$ month of exposure, these monthly averages are significantly different from control according Dunnet test. However, For GPX, Tukey's test shows that monthly concentrations increase significantly from the first month of sampling. Regarding spatial averages of enzymatic activity, results show that averages of APX, GPX and CAT recorded in site 4, 5 and 6 are significantly the highest according Tukey test. These spatial averages are significantly different from the control at $(p<0.05)$ according to Dunnet test.

Furthermore, results of the two ways ANOVA with covariates (Table 2) shows that GPX variation is very highly significant with bio accumulated $\mathrm{Pb}$, highly significant with $\mathrm{Cd}\left(\mathrm{p}=0.001^{* *}\right)$ and significant with $\mathrm{Cr}\left(\mathrm{p}=0.047^{*}\right)$.

In addition, CAT and APX variations are significant with $\mathrm{Pb}\left(\mathrm{p}=0.011^{*}\right.$ and $\mathrm{p}=0.002 * *$ respectively), very highly significant with $\mathrm{Cr}(\mathrm{p}=0.000 * * *)$. However, the variation of the two enzymes is not significant with $\mathrm{Cd}$ concentrations. Lichens react quickly to deteriorating air quality and are extremely sensitive to other types of environmental changes (Agnan et al., 2017; Belhadj, 2015). In nature, lichens are exposed to a variety of stressors including HMs (Ilondu, 2019; Paoli et al., 2018; Yemets et al., 2014). 


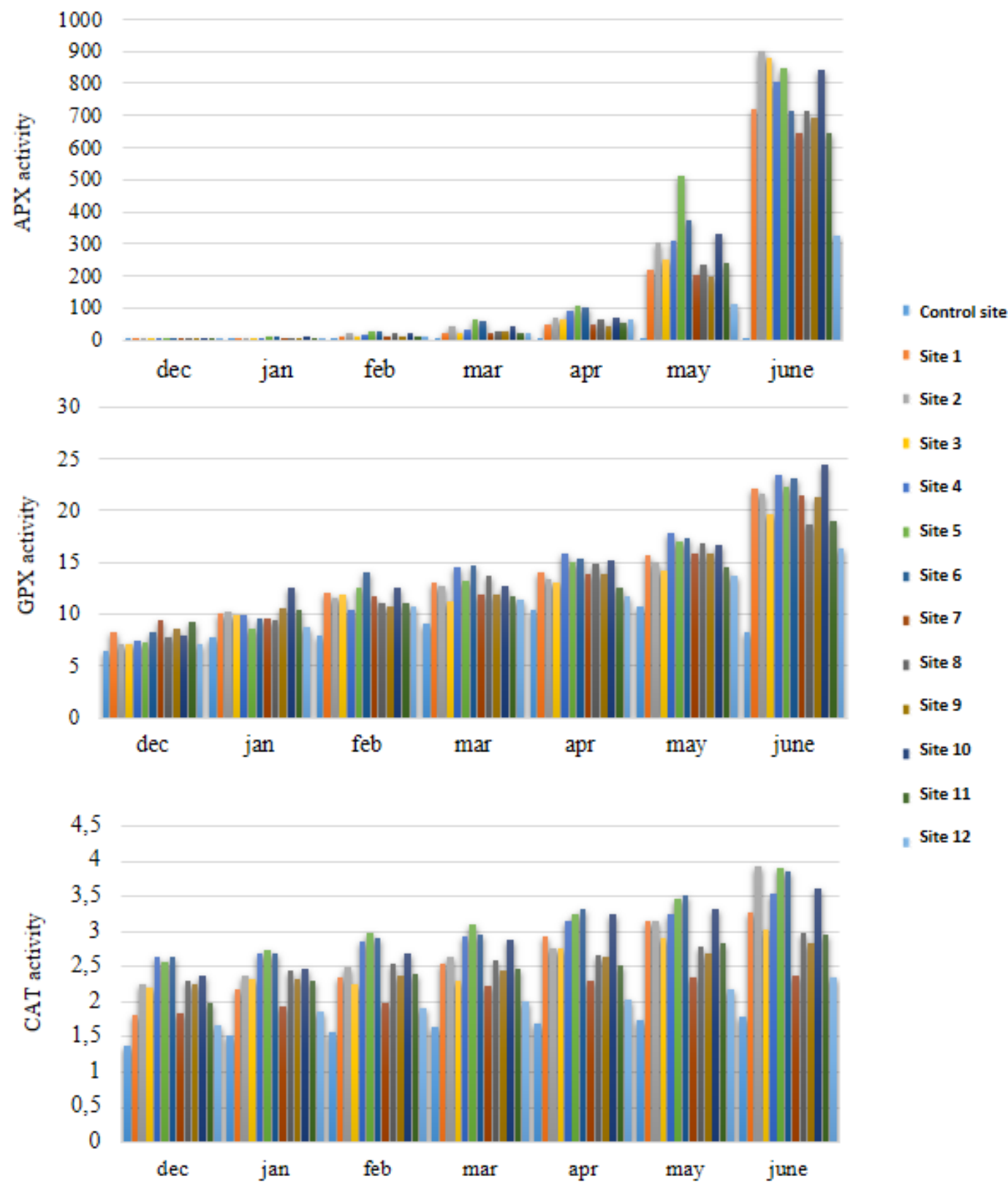

Figure 6. Spatio-temporal activity of Catalase (CAT), Ascorbate peroxidase (APX) and Guaiacol peroxidase $(G P X)($ in nmol/min/mg of protein $\times 10-8)$ in collected Lobaria pulmonaria thallus

Table 2. Two ways ANOVA with covariates. Variation of APX, GPX, and CAT activity according to the variation of heavy metal concentrations

\begin{tabular}{c|c|c|c|c|c|c|c}
\hline \multirow{2}{*}{ Sources } & \multirow{2}{*}{ DL } & \multicolumn{2}{|c|}{ APX } & \multicolumn{2}{c|}{ GPX } & \multicolumn{2}{c}{ CAT } \\
\cline { 3 - 8 } & & F value & P value & F value & P value & F value & P value \\
\hline Cd & 1 & 1.31 & 0.256 & 13.09 & $\mathbf{0 . 0 0 1}$ & 0.41 & 0.522 \\
Cr & 1 & 16.25 & $\mathbf{0 . 0 0 0}$ & 4.08 & $\mathbf{0 . 0 4 7}$ & 17.88 & $\mathbf{0 . 0 0 0}$ \\
Pb & 1 & 10.27 & $\mathbf{0 . 0 0 2}$ & 16.46 & $\mathbf{0 . 0 0 0}$ & 6.90 & $\mathbf{0 . 0 1 1}$ \\
Sites & 12 & 1.03 & 0.432 & 4.09 & 0.000 & 23.03 & 0.000 \\
Months & 6 & 35.01 & 0.000 & 12.22 & 0.000 & 3.72 & 0.003 \\
\hline
\end{tabular}



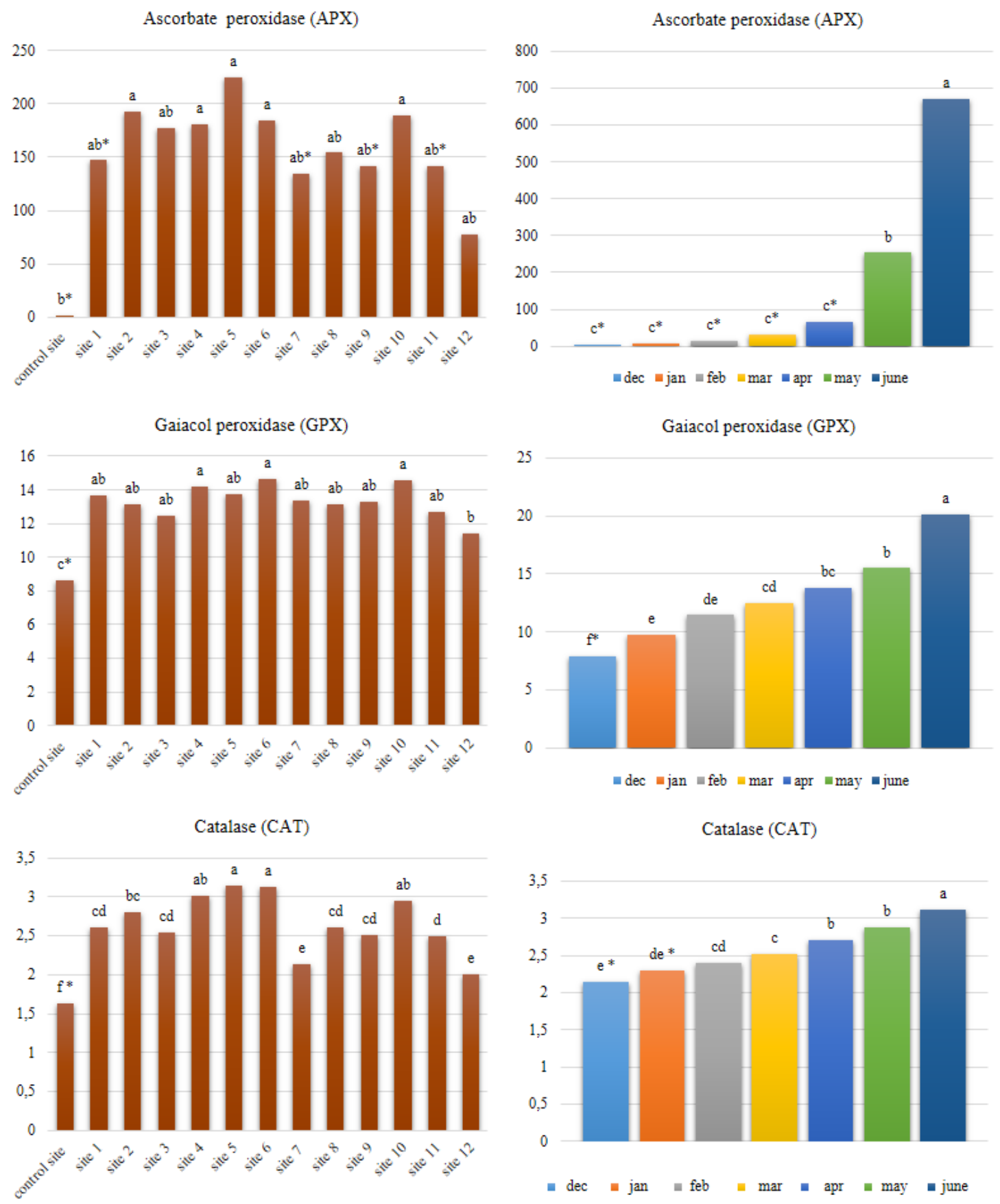

Figure 7. Means of enzymatic activity recorded in space and in time in Lobaria pulmonaria thallus. The different letters show significant differences according to Tukey's HSD $(p<0.05)$. Means not marked with a (*) are significantly different from the control site's mean according to Dunnet $(p<0.05)$

Our results reveal a highly significant spatio-temporal increase in activity of GPX and CAT, and a significant temporal increase in APX in Lobaria pulmonaria transplants. This increase is most likely due to increased antioxidant activity in cells because of reactive oxygen species formation (ROS). 
In general, at the cellular level, ROS can be produced by normal metabolisms, like photosynthesis in chlorophyll cells; the ROS production in cells is low $\left(240 \mu \mathrm{M} \mathrm{s}^{-1} 0^{2-}\right.$ and $0.5 \mu \mathrm{M} \mathrm{H}_{2} \mathrm{O}_{2}$ in chloroplast according to Polle (2001)). Several forms of stress, however, disrupt cell homeostasis and increase ROS production $\left(240-720 \mu \mathrm{M} \mathrm{s}^{-1} 0^{2-}\right.$ and 5-15 $\mu \mathrm{M} \mathrm{H}_{2} \mathrm{O}_{2}$ ) (Bouziane, 2006; Chirva et al., 2019). At low concentrations, ROS are involved in cell signaling and defense responses, stimulating cells to develop strategies that involve an important antioxidant system including non-enzymatic and enzymatic components that protect them from destructive oxidative reactions (SerradjAli Ahmed et al., 2014). Among these enzymes, catalase, APX and GPX belong to the primary defense mechanism against ROS by catalyzing the conversion of $\mathrm{H}_{2} \mathrm{O}_{2}$ to $\mathrm{H}_{2} \mathrm{O}$, however, an increased level of antioxidant components is often correlated with increased stress (Chance et al., 1979; Jaskulak et al., 2019; Serradj-Ali Ahmed et al., 2014).

Indeed, according to Cui et al. (2022) the increase in $\mathrm{H}_{2} \mathrm{O}_{2}$ and $\mathrm{O} 2{ }^{--}$levels may be correlated with stress induced by heavy metals. In fact, the increase in the three enzymes activity: APX, GPX and catalase fluctuates according to accumulated HMs concentrations, which is shown in correlation matrices (Fig. 8). significant positive correlations between bioaccumulated heavy metal concentrations and enzymatic activity, which is consistent with the results of several authors (Álvarez et al., 2015; Jaskulak et al., 2019; Serradj-Ali Ahmed et al., 2014; Cui et al., 2022). In fact, it has been proven that the heavy metals are responsible for the detoxification enzymes's activation and the increase of the expression of the gene coding for certain enzyme. However, antioxidant response in plan cells varies depending on the plant species, the type of metal ion, the metal concentration and the duration of exposure (Cui et al., 2022).

The most cytotoxic effects of HMs are indirect, through the stimulation of the production of reactive oxygen species (ROS) that alter the antioxidant defenses and generate oxidative stress (Cui et al., 2022). Indeed, many authors reported that the intracellular accumulation of HMs constitutes a potential metabolic risk for lichens, as HMs are recognized as being able to generate oxidative stress in living organisms, leading to the formation of ROS such as hydrogen peroxide $\left(\mathrm{H}_{2} \mathrm{O}_{2}\right)$ superoxide ions $\left(\mathrm{O}_{2}\right.$ -) and hydroxyl radicals $\left({ }^{\bullet} \mathrm{OH}\right)$ via Fenton or Haber-Weiss reactions (Álvarez et al., 2015; Assad, 2017).

The study of Bolan et al. (2014) in particular, confirms that the exposure to heavy metals affects redox homeostasis and leads to oxidative stress, while Cui et al. (2022) assumes that the increase in the superoxide anion levels is caused by the heavy metals accumulated by the plant. Other works shows that HMs have many toxic effects that can affect different metabolic pathways such as photosynthesis, respiration, etc. (Chiboub et al., 2019; Nash III, 2008; Vitali et al., 2019). Once inside the cell the non-essential heavy metal's response can be represented by the bell curve with only the second and third phase: tolerance and toxicity involving detoxification enzymes.

According to the statistical analysis of our results, APX levels are the highest compared to GPX and CAT, with non-significant correlations between APX and Cr, and between CAT and Cd. Indeed, the differences in affinity of APX (of the order of $\mu \mathrm{M}$ ) and catalase (of the order of $\mathrm{mM}$ ) for $\mathrm{H}_{2} \mathrm{O}_{2}$, produced in the presence of $\mathrm{HMs}$ makes the two enzymes react differently to this radical. In fact, APX acts as a messenger to activate defense systems, while catalase eliminates excess $\mathrm{H}_{2} \mathrm{O}_{2}$ during stress (Bouziane, 2006). 


$$
-4734-
$$

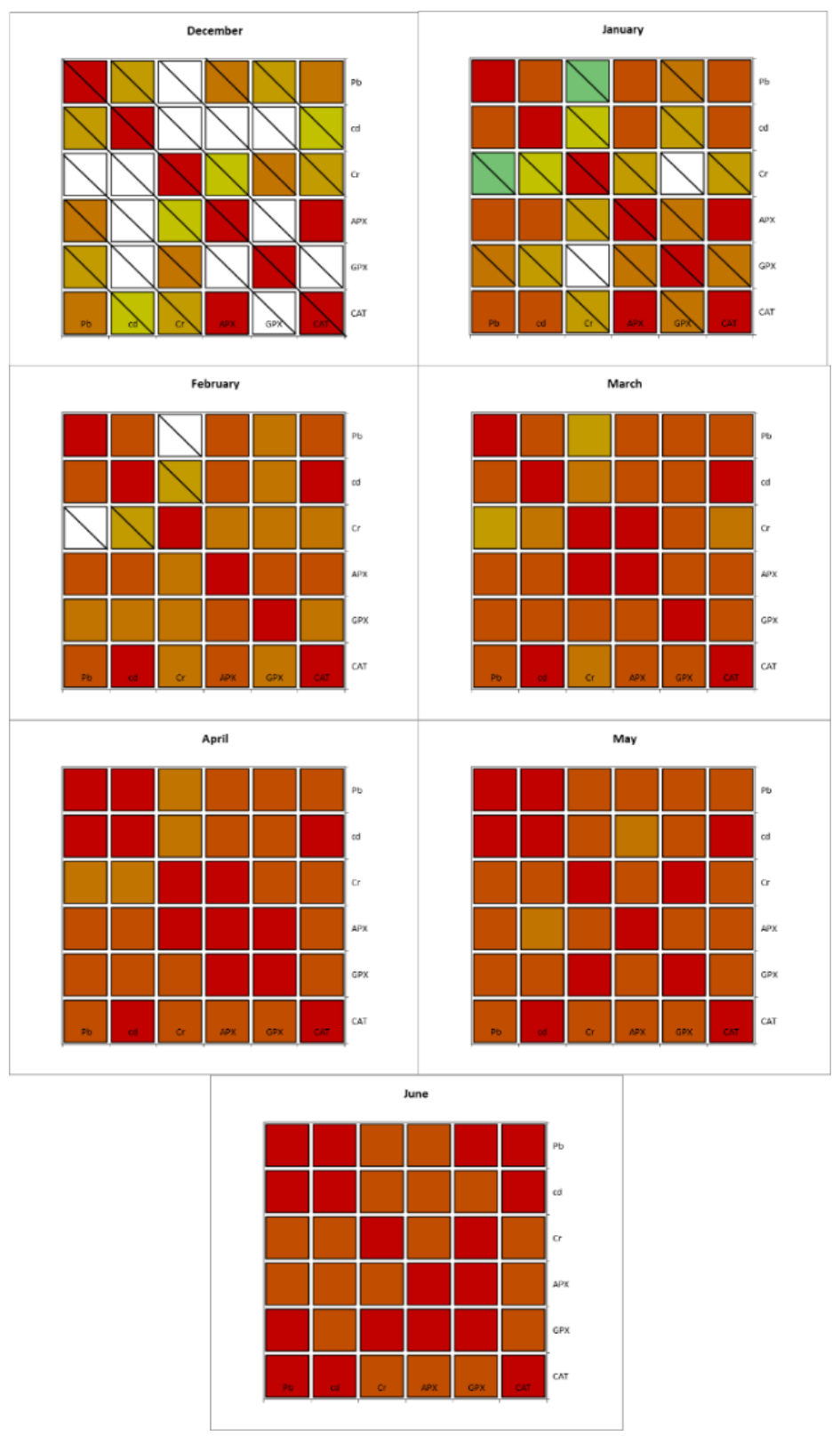

Figure 8. Correlation between heavy metal concentrations and enzyme activity. Based on a color scale from blue to red (cold-hot scale) to display correlations. The blue color corresponds to a negative correlation close to -1 and the red color corresponds to a positive correlation close to 1, the crossed boxes represent non-significant correlations

\section{Conclusion}

The active bio-monitoring of air quality in the Oran region, the first study of its kind to be conducted in this region, using the foliaceous lichen Lobaria pulmonaria has made it possible, on the one hand, to assess and locate air pollution in the region through the interpretation of the concentrations of HMs bio-accumulated by the transplants, which testifies to the bio-accumulative power of the studied bio-indicators. And at the same time, to understand the impact of air pollution in the studied region on the physiological parameters of the lichen Lobaria pulmonaria, the focus of our study, notably through the activation of the detoxification enzyme system, notably APX, GPX 
and CAT. The study area lacks air quality bio monitoring studies as well as the air quality monitoring systems, the current research serves valuable information about air quality in this region which should be taken into consideration by the authorities, and which in particular can be used as a reference for long-term monitoring of pollution in the same region. Future studies should focus on the measurement of heavy metal concentration in the atmosphere in parallel with the detection of their concentration in lichens, and should focus also as on the study of the impact of air pollution on climate change.

Acknowledgements. We would like to thank the DGRSDT for sponsoring this project.

\section{REFERENCES}

[1] Abas, A., Sulaiman, N., Adnan, N. R., Aziz, S. A., Nawang, W. N. S. W. (2019): Using lichen (dirinaria sp.) as bio-indicator for airborne heavy metal at selected industrial areas in malaysia. - Environment Asia 12(3): 85-90.

[2] Agnan, Y., Probst, A., Séjalon-Delmas, N. (2017): Evaluation of lichen species resistance to atmospheric metal pollution by coupling diversity and bioaccumulation approaches: a new bioindication scale for French forested areas. - Ecological Indicators 72: 99-110.

[3] Akomolafe, G., David, O., Nkemdy, A. (2019): Comparative anatomical studies of responses of some roadside plants to highway automobile exhausts. - Journal of Research in Forestry, Wildlife 11(3): 246-255.

[4] Alami, F. O., Elabidi, A., Mouhir, L., Fekhaoui, M. (2014): Utilisation des lichens comme bio-indicateurs de la pollution atmosphérique par le plomb, cadmium et zinc de la région de Rabat-Sale-Zemmour-Zaêr (Maroc). - Afrique Science: Revue Internationale des Sciences et Technologie 10(3): 89-106.

[5] Alioua, A. (1995): Détection de la pollution mercurielle dans la région de Azzaba (Algérie orientale) à l'aide de bioaccumulateurs (Xanthoria parietina, Olea europea, Cupressus sempervirens, Casuarina equisetifolia et Triticum durum). - Magister thesis in ecotoxicology, Université Badji Mokhtar Annaba, Algeria.

[6] Alioua, A. (2001): Détection de la pollution plombique d'origine automobile à l'aide de bio-accumulateurs végétaux dans l'agglomération de Skikda (NE Algérie). - Doctoral thesis in ecotoxicology, Université Joseph Fourier (Grenoble), Greboble, France.

[7] Alioua, A., Maizi, N., Maizi, L., Tahar, A. (2008): Caractérisation de la pollution par le NO2 à l'aide d'un couplage de technique biologique et physico-chimique dans la région d'Annaba (Algérie). - Pollution Atmosphérique 50(200): 325-332.

[8] Álvarez, R., Del Hoyo, A., Díaz-Rodríguez, C., Coello, A. J., Del Campo, E., Barreno, E., Catalá, M., Casano, L. M. (2015): Lichen rehydration in heavy metal-polluted environments: $\mathrm{Pb}$ modulates the oxidative response of both Ramalina farinacea thalli and its isolated microalgae. - Microbial Ecology 69(3): 698-709.

[9] Angold, P. G. (1997): The impact of a road upon adjacent heathland vegetation: effects on plant species composition. - Journal of Applied Ecology 34(2): 409-417.

[10] Assad, M. (2017): Transfert des éléments traces métalliques vers les végétaux: mécanismes et évaluations des risques dans des environnements exposés à des activités anthropiques. - Doctoral thesis école doctorale environnement et santé, Université Bourgogne Franche-Comté, Franche-Comté.

[11] Belhadj, H. (2015): Détection de la pollution atmosphérique à l'aide du lichen Xanthoria parietina (L.) bio-accumulateur d'éléments traces métalliques dans le centre urbain de la ville de Sidi Bel Abbés (Algérie occidentale). - Doctoral thesis in science, sciences de l'environnement, Université Djillali Liabes de SBA, Algeria. 
[12] Bendaikha, Y., Hadjadj-Aoul, S. (2016): Diversity of lichens flora in Oran area (northwestern Algeria). - Advances in Environmental Biology 10(7): 180-191.

[13] Bolan, N., Kunhikrishnan, A., Thangarajan, R., Kumpiene, J., Park, J., Makino, T. (2014): Remediação de solos contaminados com metais pesados (em movimento)Mobilizar ou imobilizar. - Hazard Mater 266: 141-166.

[14] Bouteraa, M. (2014): Utilisation des végétaux pour l'évaluation de la pollution atmosphérique le long de l'autoroute Est-Ouest dans la région de Constantine. - Magister thesis, Département de biologie végétale et écologie, Université Constantine 1, constantine, Algeria.

[15] Bouziane, M. (2006): Étude physico-chimique de l'accumulation de métaux lourds par les lichens: impacts sur les voies de biosynthèse et interprétation du mécanisme de tolérance chez Diploschistes muscorum. - Doctoral thesis, Ecole Doctorale des Sciences pour l'Ingénieur de Lille, Université des Sciences et Technologies de Lille, France.

[16] Brodo, I. M. (1961): Transplant experiments with corticolous lichens using a new technique. - Ecology 42(4): 838-841.

[17] Cakmaki, H. (1991): Effect of aluminium on lipid peroxidation, superoxide dismutase, catalase, and peroxide activities in root tips of soybean. - PhysiolPlant 83(3): 463-468.

[18] Carlsson, R., Nilsson, K. (2009): Status of the red-listed lichen Lobaria pulmonaria on the Åland Islands, SW Finland. - Annales Botanici Fennici, BioOne, 549-554.

[19] Chance, B., Sies, H., Boveris, A. (1979): Hydroperoxide metabolism in mammalian organs. - Physiological Reviews 59(3): 527-605.

[20] Chiboub, M., Jebara, S. H., Abid, G., Jebara, M. (2019): Co-inoculation effects of Rhizobium sullae and Pseudomonas sp. on growth, antioxidant status, and expression pattern of genes associated with heavy metal tolerance and accumulation of cadmium in Sulla coronaria. - Journal of Plant Growth Regulation 39: 1-13.

[21] Chirva, O. V., Nikerova, K. M., Androsova, V. I., Ignatenko, R. V. (2019): Activity of catalase and superoxide dismutase in Lobaria pulmonaria from forest communities of middle and northernmost boreal zone (NW Russia). - Czech Polar Reports 9(2): 228-242.

[22] Çomakl1, E., Bingöl, M. S. (2021): Heavy metal accumulation of urban Scots pine (Pinus sylvestris L.) plantation. - Environmental Monitoring Assessment 193(4): 1-13.

[23] Cui, N., Qu, L., Wu, G. J. J. O. E. S. (2022): Heavy metal accumulation characteristics and physiological response of Sabina chinensis and Platycladus orientalis to atmospheric pollution. - Journal of Environmental Sciences 112: 192-201.

[24] Deruelle, S. (1978): Etude comparee de la sensibilite de trois methodes d'estimation de la pollution atmospherique, en utilisant les lichens comme indicateurs biologiques, dans la region de Mantes (Yvelines). - Rev. Bryol. Lichenol 44(4): 429-441.

[25] Déruelle, S. (1983): Les Lichens Témoins De La Pollution. - Vuibert, Paris.

[26] DOE (2018): Directorate of Environment of Oran city. - DOE, Oran.

[27] Fielding, J. L., Hall, J. (1978): A biochemical and cytochemical study of peroxidase activity in roots of Pisum sativum: II. Distribution of enzymes in relation to root development. - Journal of Experimental Botany 29(4): 983-991.

[28] Garrec, J., Van Haluwyn, C. (2002): Biosurveillance végétale de la qualité de l'air e Concepts, méthodes et applications (Air Quality Biomonitoring with Plants e Concepts, Methods and Applications). - Lavoisier, Paris.

[29] Garty, J., Kloog, N., Cohen, Y. (1998): Integrity of lichen cell membranes in relation to concentration of airborne elements. - Archives of Environmental Contamination Toxicology 34(2): 136-144.

[30] Guelorget, O., Frisoni, G., Monti, D., Perthuisot, J. (1986): Contribution à l'étude écologique des lagunes septentrionales de la baie d'Amvrakia (Grèce). - Oceanologica Acta 9(1): 9-17.

[31] Hamutoğlu, R., Aslan, A., Aras, S., Cansaran-Duman, D. (2017): Environmental risk assessment under the pollutants exposure with using four lichen species and molecular assay in cement plant, Aşkale-Erzurum (Turkey). - Cancer 73(3): 253-266. 
[32] Ilondu, E. (2019): Occurrence and diversity of Lichens in Abraka and its environs, Delta State, Nigeria. - Journal of Applied Sciences Environmental Management 23(5): 947951.

[33] Jaskulak, M., Rorat, A., Grobelak, A., Chaabene, Z., Kacprzak, M., Vandenbulcke, F. (2019): Bioaccumulation, antioxidative response, and metallothionein expression in Lupinus luteus L. exposed to heavy metals and silver nanoparticles. - Environmental Science Pollution Research 26(16): 16040-16052.

[34] Jiang, Y., Fan, M., Hu, R., Zhao, J., Wu, Y. (2018): Mosses are better than leaves of vascular plants in monitoring atmospheric heavy metal pollution in urban areas. International Journal of Environmental Research 15(6): 1-13.

[35] Kadri, Y., Madani, M. (2015): L'agglomération oranaise (Algérie) entre instruments d'urbanisme et processus d'urbanisation. - EchoGéo 34: 1-20.

[36] Kaur, M., Bhatti, S. S., Katnoria, J. K., Nagpal, A. K. (2021): Investigation of metal concentrations in roadside soils and plants in urban areas of Amritsar, Punjab, India, under different traffic densities. - Environmental Monitoring Assessment 193(4): 1-20.

[37] Kłos, A., Ziembik, Z., Rajfur, M., Dołhańczuk-Śródka, A., Bochenek, Z., Bjerke, J. W., Tømmervik, H., Zagajewski, B., Ziółkowski, D., Jerz, D. (2018): Using moss and lichens in biomonitoring of heavy-metal contamination of forest areas in southern and northeastern Poland. - Science of the Total Environment 627: 438-449.

[38] Loggini, B., Scartazza, A., Brugnoli, E., Navari-Izzo, F. (1999): Antioxidative defense system, pigment composition, and photosynthetic efficiency in two wheat cultivars subjected to drought. - Plant Physiology 119(3): 1091-1100.

[39] Mahapatra, B., Dhal, N. K., Dash, A. K., Panda, B. P., Panigrahi, K. C. S., Pradhan, A. (2019): Perspective of mitigating atmospheric heavy metal pollution: using mosses as biomonitoring and indicator organism. - Journal Environmental Science Pollution Research 26(29): 29620-29638.

[40] Maizi, N., Alioua, A. (2015): Evaluation of levels of lead pollution from automobiles near Highway using phanerogamic and cryptogamic species in the city of Annaba (Algeria). - IJSRST 1(6): 33-43.

[41] Mcadam, K., Steer, P., Perrotta, K. (2011): Using continuous sampling to examine the distribution of traffic related air pollution in proximity to a major road. - Atmospheric Environment 45(12): 2080-2086.

[42] Nakano, Y., Asada, K. (1987): Purification of ascorbate peroxidase in spinach chloroplasts; its inactivation in ascorbate-depleted medium and reactivation by monodehydroascorbate radical. - Plant Cell Physiology 28(1): 131-140.

[43] Nash Iii, T. H. 2008. Lichen Sensitivity to Air Pollution. - In: Nash, T., III (ed.) Lichen Biology. 2nd Ed. Cambridge University Press, Cambridge, UK.

[44] Nimis, P. L., Scheidegger, C., Wolseley, P. A. (2002): Monitoring with LichensMonitoring Lichens. - Springer, Dordrecht.

[45] OTD (2018): Oran Transport Direction. - OTD, Oran.

[46] Pagotto, C., Remy, N., Legret, M., Le Cloirec, P. (2001): Heavy metal pollution of road dust and roadside soil near a major rural highway. - Environmental Technology 22(3): 307-319.

[47] Paoli, L., Vannini, A., Fačkovcová, Z., Guarnieri, M., Bačkor, M., Loppi, S. (2018): One year of transplant: is it enough for lichens to reflect the new atmospheric conditions? Ecological Indicators 88: 495-502.

[48] Polle, A. J. P. P. (2001): Dissecting the superoxide dismutase-ascorbate-glutathionepathway in chloroplasts by metabolic modeling. Computer simulations as a step towards flux analysis. - Plant Physiology 126(1): 445-462.

[49] Rahal, F., Hadjou, Z., Blond, N., Aguejdad, R. J. C. E. J. O. G. (2018): Croissance urbaine, mobilité et émissions de polluants atmosphériques dans la région d'Oran, Algérie. - Cybergeo. https://doi.org/10.4000/cybergeo.29111 
[50] Rahali, M. (2002): Mapping of lead pollution in Algiers area with a lichen (Xanthoria parietina) as indicator. - Pollution Atmosphérique 44(175): 421-432.

[51] Rahma, K., Aminata, O. E. H.-K., Belkeir, D., Francisc, C.-H., Marie-André, E. (2014): EFFET DE LA Pollution Atmospherique Par Les Hydrocarbures Sur Le Lichen Xanthoria Parietina (L.) Th (Teloschistaceae) Dans La Zone De Hassi Messaoud (Sahara Septentrional Est Algerien). - Algerian Journal of Arid Environment "AJAE" 4(2): 98106.

[52] Ramade, F. (2007): Introduction à l'écotoxicologie: fondements et applications. - Tec \& Doc, Paris.

[53] Rola, K. (2020): Insight into the pattern of heavy-metal accumulation in lichen thalli. Journal of Trace Elements in Medicine 61: 126512.

[54] Semadi, A., Deruelle, S. (1993): Détection de la pollution plombique à l'aide de transplants lichéniques dans la région de Annaba (Algérie). - Pollution Atmosphérique 86: 86-102.

[55] Serradj-Ali Ahmed, M., Boumedris, Z., Djebar, M., Tahar, A. (2014): Responses of antioxidants in Flavoparmelia caperata (L.) Hale to the atmospheric pollution air at two urban and semi-urban areas in the region of Annaba (East of Algeria). - Pollution Atmosphérique 221. https://doi.org/10.4267/pollution-atmospherique.2674.

[56] Shahid, M., Dumat, C., Khalid, S., Schreck, E., Xiong, T., Niazi, N. K. (2017): Foliar heavy metal uptake, toxicity and detoxification in plants: a comparison of foliar and root metal uptake. - Journal of Hazardous Materials 325: 36-58.

[57] Škrbić, B., Milovac, S., Matavulj, M. (2012): Multielement profiles of soil, road dust, tree bark and wood-rotten fungi collected at various distances from high-frequency road in urban area. - Ecological Indicators 13(1): 168-177.

[58] Stankevich, S., Titarenko, O., Kharytonov, M., Benselhoub, A., Bounouala, M., Chaabia, R., Boukeloul, M.-L. (2015): Mapping of urban atmospheric pollution in the northern part of Algeria with nitrogen dioxide using satellite and ground-truth data. - Studia Universitatis "Vasile Goldis" Arad. Seria Stiintele Vietii 25(2): 87-92.

[59] Tkalec, M., Štefanić, P. P., Cvjetko, P., Šikić, S., Pavlica, M., Balen, B. (2014): The effects of cadmium-zinc interactions on biochemical responses in tobacco seedlings and adult plants. - Plos One 9(1): e87582.

[60] Tyler, G. (1989): Uptake, retention and toxicity of heavy metals in Lichens. - Water, Air, Soil Pollution 47(3): 321-333.

[61] Viskari, E.-L., Kärenlampi, L. (2000): Roadside Scots pine as an indicator of deicing salt use-a comparative study from two consecutive winters. - Water, Air, Soil Pollution 122(3): 405-419.

[62] Vitali, M., Antonucci, A., Owczarek, M., Guidotti, M., Astolfi, M. L., Manigrasso, M., Avino, P., Bhattacharya, B., Protano, C. (2019): Air quality assessment in different environmental scenarios by the determination of typical heavy metals and Persistent Organic Pollutants in native lichen Xanthoria parietina. - Environmental Pollution 254(part A): 113013.

[63] WHO (2018): Ambient Outdoor Air Pollution. - World Health Organisation, Geneva.

[64] Yemets, O. A., Solhaug, K. A., Gauslaa, Y. J. T. L. (2014): Spatial dispersal of airborne pollutants and their effects on growth and viability of lichen transplants along a rural highway in Norway. - The Lichenologist 46(6): 809-823. 